\title{
Liver Cancer pT4 TNM Finding v7
}

National Cancer Institute

\section{Source}

National Cancer Institute. Liver Cancer pT4 TNM Finding V7. NCI Thesaurus. Code C90163.

Liver cancer with tumor(s) with direct invasion of adjacent organs other than the gallbladder or with perforation of visceral peritoneum. (from AJCC 7th Ed.) 